\title{
Minimalnofazowość układu a fizyczny model dla eksperymentu w badaniach dynamiki pojazdów szynowych
}

\begin{abstract}
$W$ artykule badano wptyw modelu typu wejście-wyjście tworzonego dla eksperymentu $w$ badaniach dynamiki pojazdu na to, czy uktad jest minimalnofazowy czy nie. Dla przyjętego modelu wyznaczono położenie zer i biegunów transmitancji układu oraz analizowano wpływ zer leżacych w prawej pótpłaszczyźnie zespolonej na rozwiqzanie wybranych problemów dynamiki pojazdu.
\end{abstract}

\section{Wprowadzenie}

Dynamika liniowego, stacjonarnego układu mechanicznego o wielu stopniach swobody oraz o wielu wejściach i wyjściach reprezentowana jest macierza transmitancji operatorowej i widmowej. Elementy macierzy transmitancji są $\mathrm{w}$ takim przypadku przyczynowymi funkcjami wymiernymi zmiennej zespolonej.

Miejsca zerowe mianowników elementów macierzy transmitancji nazwano biegunami, a miejsca zerowe liczników elementów macierzy transmitancji - zerami. Bieguny są interpretowane fizycznie jako częstotliwości rezonansowe, a zera jako częstotliwości antyrezonansowe [2].

W celu wyznaczenia macierzy transmitancji prowadzony jest eksperyment. Tworzenie fizycznego modelu eksperymentu polega na wyborze mierzonych wielkości wejściowych (wymuszenia) i wyjściowych (odpowiedzi) co do ich liczby, punktów rozmieszczenia i kierunków pomiaru. Bieguny transmitancji są charakterystyką danego układu, natomiast zera transmitancji wynikają z rozkładu punktów przyłożenia wymuszenia i punktów pomiaru odpowiedzi.

W procesie tworzenia modelu istotne jest określenie położenia zer i biegunów na płaszczyźnie zespolonej. Jeśli bieguny transmitancji przyjmują wartości z lewej półpłaszczyzny zespolonej, to układ nazywa się stabilny. Natomiast, gdy choć jeden z biegunów leży w prawej półpłaszczyźnie zespolonej, to układ nazywa się niestabilny. Jeśli zera transmitancji przyjmują wartości z lewej półpłaszczyzny zespolonej, to układ jest minimalnofazowy. Natomiast, gdy choć jedno zero leży w prawej półpłaszczyźnie zespolonej, to układ nie jest minimalnofazowy $[4,5]$.

W pojazdach coraz częściej stosowane są układy aktywne, a w badaniach stanowiskowych wykorzystywane są układy regulacji automatycznej. Zera transmitancji leżące $\mathrm{w}$ prawej półpłaszczyźnie zespolonej są istotnym ograniczeniem wysokiej jakości procesu regulacji tak w przypadku regulacji typu feedback, jak i regulacji typu feedforward $[4,8]$.
Dynamika układów nośnych pojazdów modelowana jest $\mathrm{z}$ zastosowaniem analizy modalnej i metody elementów skończonych. Problem wyboru liczby modów $\mathrm{w}$ procesie regulacji wymaga przeprowadzenia analizy, czy układ po redukcji pozostaje minimalnofazowym $[2,7]$.

W badaniach pojazdów jest trudno bezpośrednio zmierzyć wymuszenia działające na pojazd. W celu wyznaczenia wymuszeń przy znanym układzie i znanej odpowiedzi rozwiązuje się zatem tak zwane zagadnienie odwrotne. Na uwarunkowanie zadania odwrotnego istotny wpływ ma położenie zer na płaszczyźnie zespolonej [3,5]. Szybki rozwój techniki cyfrowej $\mathrm{w}$ badaniach eksperymentalnych zwiazzany jest $\mathrm{z}$ zastosowaniem regulatorów cyfrowych. Wymaga to przeprowadzenia dyskretyzacji wybranych sygnałów ciagłych, a zadanie ciagłe przekształcane jest w dyskretne. O ile istnieje jednoznaczne przyporządkowanie biegunów układu ciagłego biegunom układu dyskretnego, to przyporządkowanie zer układu ciagłego zerom układu dyskretnego jest niejednoznaczne $[1,8]$.

Celem artykułu jest wyznaczenie wpływu przyjętego modelu typu wejście-wyjście dla eksperymentu na minimalnofazowość układu. Dla przyjętego modelu wyznaczono położenie zer i biegunów transmitancji dla układu ciagłego i układu dyskretnego. Przeprowadzono badania wpływu rzędu modelu na położenie zer i biegunów.

Wyznaczono wpływ położenia zer w prawej półpłaszczyźnie zespolonej na uwarunkowanie zagadnienia odwrotnego.

\section{Badanie minimalnofazowości układu}

Badanie rozkładu zer na płaszczyźnie zespolonej przeprowadzono dla ciagłego i dyskretnego modelu układu. Równania ruchu liniowego, stacjonarnego modelu układu mechanicznego o $n$-stopniach swobody przedstawiono $\mathrm{w}$ postaci:

$$
\mathbf{M} \ddot{\mathbf{q}}+\mathbf{D} \dot{\mathbf{q}}+\mathbf{K q}=\mathbf{B f}
$$


a równanie wyjść jako:

$$
\mathbf{y}=\mathbf{C q}
$$

gdzie:

$\mathbf{q}, \quad \dot{\mathbf{q}}, \quad \ddot{\mathbf{q}}$ - wektory współrzędnych, prędkości i przyśpieszeń uogólnionych $\left(\mathbf{q} \in \mathfrak{R}^{n \times n}\right)$,

f - wektor wymuszeń $\mathrm{W}$ postaci sił $\left(\mathbf{f} \in \mathfrak{R}^{m \times 1}\right)$,

y - wektor wielkości mierzonych $\mathrm{w}$ postaci przemieszczeń $\left(\mathbf{y} \in \mathfrak{R}^{p \times 1}\right)$,

$\mathbf{M}, \mathbf{D}, \mathbf{K}$ - macierze bezwładności, thumienia i sztywności ( $\mathbf{M}, \mathbf{D}, \mathbf{K} \in \mathfrak{R}^{n \times n}$ ),

B $\quad-$ macierz wejść rzędu $m\left(\mathbf{B} \in \mathfrak{R}^{n \times m}\right)$,

C $\quad-$ macierz wyjść rzędu $p\left(\mathbf{C} \in \mathfrak{R}^{p \times n}\right)$,

przy czym macierze $\mathbf{M}, \mathbf{D}, \mathbf{K}$ spełniają warunki:

$\mathbf{M}=\mathbf{M}^{T}>0, \mathbf{D}=\mathbf{D}^{T} \geq 0$ oraz $\mathbf{K}=\mathbf{K}^{T} \geq 0$.

Po wprowadzeniu $2 n$-wymiarowego wektora stanu w postaci:

$$
\mathbf{x}=\left[\begin{array}{c}
\mathbf{q} \\
\dot{\mathbf{q}}
\end{array}\right]
$$

równanie (1) przedstawiono jako:

$$
\dot{\mathbf{x}}=\mathbf{A x}+\mathbf{G u}
$$

a równanie (2)

$$
\mathbf{w}=\mathbf{Z} \mathbf{x}
$$

gdzie macierz A:

$$
\mathbf{A}=\left[\begin{array}{cc}
0 & \mathbf{E} \\
-\mathbf{M}^{-1} \mathbf{K} & -\mathbf{M}^{-1} \mathbf{D}
\end{array}\right]
$$

o wymiarze $2 n \times 2 n$ jest nazywana macierzą stanu, macierz $\mathbf{G}$ o wymiarze $2 \mathrm{n} \times \mathrm{p}$ nazywana jest macierza wejść, a macierz $\mathbf{Z}$ o wymiarze $r \times 2 n$ macierzą wyjść. Przez $\mathbf{E}$ oznaczono macierz jednostkową o wymiarze $n \times n$.

Model dyskretny odpowiadający modelowi ciagłemu jak w równaniach (4) i (5) ma postać:

$$
\begin{gathered}
\mathbf{x}((k+1) T)=\mathbf{\Phi} \mathbf{x}(k T)+\boldsymbol{\Theta u}(k T) \\
\mathbf{w}(k T)=\mathbf{Z} \mathbf{x}(k T)
\end{gathered}
$$

gdzie $T$ jest okresem próbkowania. Macierz $\Phi$ ma postać:

$$
\boldsymbol{\Phi}=e^{\mathbf{A} T}
$$

oraz macierz $\Theta$ ma postać:

$$
\boldsymbol{\Theta}=\int_{0}^{T} e^{\mathbf{A} t} \mathbf{G} d t
$$

Transmitancja jako funkcja wymierna zmiennej operatorowej $s$ dla ciągłych modeli układów nośnych pojazdów ma postać:

$$
H(s)=k \frac{\left(s-z_{1}\right) \ldots\left(s-z_{m}\right)}{\left(s-p_{1}\right) \ldots\left(s-p_{n}\right)}
$$

dla $n \geq m+2$.

Dla układu dyskretnego transmitancja przyjmie postać:

$$
H(\hat{z})=g_{1}(T) \hat{z}^{-1}+g_{2}(T) \hat{z}^{-2}+\ldots
$$

Zera modelu układu ciagłego wyznaczono znajdując pierwiastki równania $|\boldsymbol{\Gamma}(s)|=0$, gdzie $\boldsymbol{\Gamma}(s)$ jest określona równaniem:

$$
\Gamma(s)=\left[\begin{array}{cc}
\mathbf{A}-s \mathbf{E} & \mathbf{G} \\
\mathbf{Z} & \mathbf{0}
\end{array}\right]
$$

gdzie $s$ jest ciągłą zmienną operatorową.

Zera modelu układu dyskretnego wyznaczono znajdując pierwiastki równania:

$$
\boldsymbol{\Gamma}_{T}(\hat{z})=\left[\begin{array}{cc}
\boldsymbol{\Phi}-\hat{z} \mathbf{E} & \boldsymbol{\Theta} \\
\mathbf{Z} & \mathbf{0}
\end{array}\right]
$$

gdzie $\hat{z}$ jest dyskretną zmienną operatorową.

\section{Wpływ rzędu modelu układu na położenie zer na płaszczyźnie zespolonej}

W badaniach dynamiki konstrukcji nośnych pojazdów stosowana jest analiza modalna. Macierz thumienia D ma wtedy postać:

$$
\mathbf{D}=\alpha \mathbf{K}+\beta \mathbf{M}
$$

Wprowadzenie macierzy thumienia $\mathrm{w}$ postaci (15) umożliwia diagonalizację macierzy układu. Postacie modów $\boldsymbol{\Psi}_{k}$, częstotliwości $\omega_{k}$ i bezwymiarowe współczynniki thumienia $d_{\mathrm{k}}$ wyznacza się rozwiązując uogólniony problem własny. Współrzędne główne p spełniają zależność:

$$
\mathbf{q}=\mathbf{\Psi p}
$$

gdzie $\boldsymbol{\Psi}=\left[\begin{array}{llll}\boldsymbol{\Psi}_{1} & \boldsymbol{\Psi}_{2} & \ldots & \boldsymbol{\Psi}_{n}\end{array}\right]$.

Równanie układu we współrzędnych głównych ma postać:

$$
\ddot{\mathbf{p}}+\Pi \dot{\mathbf{p}}+\Lambda \mathbf{p}=\boldsymbol{\Psi}^{T} \mathbf{B f}
$$

gdzie: $\quad \boldsymbol{\Lambda}=\operatorname{diag}\left[\omega_{1}^{2} \quad \omega_{2}^{2} \quad \ldots \quad \omega_{n}^{2}\right]$, $\boldsymbol{\Pi}=\operatorname{diag}\left[\begin{array}{llll}2 d_{1} \omega_{1} & 2 d_{2} \omega_{2} & \ldots & 2 d_{n} \omega_{n}\end{array}\right]$. 
W modelu uwzględnianych jest zwykle niewiele modów odpowiadających najmniejszym częstotliwościom własnym modelu układu. Szczególnie istotne jest badanie wpływu rzędu modelu układu na położenie zer na płaszczyźnie zespolonej ze względu na spełnienie wymagań dotyczących jakości układu regulacji.

\section{Rozwiązanie zagadnienia odwrotnego w przy- padku gdy układ nie jest minimalnofazowy}

W badaniach eksperymentalnych pojazdów szczególnie trudny jest pomiar wymuszeń działających na pojazd. Zakładając znajomość odpowiedzi impulsowej układu oraz znajomość pomierzonego wyjścia, wyznaczanie wejścia jest interpretowane jako zagadnienie odwrotne.

Przyjmując, że wejściem jest $f(t)$, a wyjściem jest $y(t)$, związek między wyjściem a wejściem zapisano w postaci całki splotu:

$$
y(t)=\int_{0}^{\infty} g(\tau) f(t-\tau) d \tau
$$

gdzie $g(\tau)$ jest odpowiedzią impulsową.

Dyskretny odpowiednik równania (18) ma postać:

$$
y(n)=\sum_{m=0}^{n} g(m) f(n-m)
$$

gdzie $n$ i $m$ oznaczają kolejne wartości dyskretne odpowiednich sygnałów.

Równanie (19) może być przedstawione w postaci macierzowej przez wyznaczenie wartości dla kolejnych $n=0,1, \ldots, \mathrm{N}$ :

$$
\begin{gathered}
y(0)=g(0) f(0) \\
y(1)=g(1) f(0)+g(0) f(1) \\
\ldots \\
y(\mathrm{~N})=g(\mathrm{~N}) f(0)+\ldots+g(0) f(\mathrm{~N})
\end{gathered}
$$

lub w postaci macierzowej:

$$
\mathbf{y}=\mathbf{P f}
$$

gdzie macierz $\mathbf{P}$ jest równa:

$$
\mathbf{P}=\left[\begin{array}{ccccc}
g(0) & 0 & 0 & \ldots & 0 \\
g(1) & g(0) & 0 & \ldots & 0 \\
g(2) & g(1) & g(0) & \ldots & 0 \\
g(3) & g(2) & g(1) & \ldots & 0 \\
\ldots & \ldots & \ldots & \ldots & \ldots
\end{array}\right]
$$

a wektor $\mathbf{f}$ ma postać:

$$
\mathbf{f}=\left[\begin{array}{c}
f(0) \\
f(1) \\
\cdots \\
f(N)
\end{array}\right] .
$$

W celu znalezienia wejścia (wymuszenia) rozwiązano zagadnienie odwrotne otrzymując zależność:

$$
\mathbf{f}=\mathbf{P}^{+} \mathbf{y}
$$

gdzie $\mathbf{P}^{+}$jest macierzą Penrose.

Skutecznym narzędziem algebry liniowej rozwiązywania zadania odwrotnego jest rozkład macierzy względem jej wartości szczególnych [6]. Rozkład macierzy $\mathbf{P}(m, n)$ względem jej wartości szczególnych jest faktoryzacją o postaci:

$$
\mathbf{P}=\mathbf{U} \Sigma \mathbf{V}^{*}
$$

gdzie $\mathbf{U}$ i $\mathbf{V}$ są macierzami unitarnymi o odpowiednich wymiarach, gwiazdka $(*)$ oznacza macierz sprzężoną, a macierz $\Sigma$ ma postać:

$$
\boldsymbol{\Sigma}=\left[\begin{array}{ll}
\boldsymbol{\Xi} & 0 \\
\mathbf{0} & 0
\end{array}\right]
$$

gdzie $\Xi=\operatorname{diag}\left[\sigma_{1} \sigma_{2} \ldots \sigma_{\mathrm{r}}\right]$ jest diagonalną macierzą wartości szczególnych, które spełniają relacje $\sigma_{1}>\sigma_{2}$ $>\ldots>\sigma_{\mathrm{r}}>0$.

Liczbę niezerowych wartości szczególnych definiuje rząd $r$ macierzy P. Dla zbadania wpływu nieminimalnej fazowości układu na stopień uwarunkowania zadania odwrotnego przyjęto normę $\mathrm{w}$ postaci stosunku największej wartości szczególnej do najmniejszej wartości szczególnej macierzy, co zapisano równaniem:

$$
\text { cond } \mathbf{P}=\frac{\sigma_{r}}{\sigma_{1}}
$$

\section{Przyklad obliczeniowy}

Do badań przyjęto dyskretny model belki dwupodporowej, opisanej pięciowymiarowym wektorem wspó1rzędnych uogólnionych q:

$$
\mathbf{q}=\left[\begin{array}{lllll}
q_{1} & q_{2} & q_{3} & q_{4} & q_{5}
\end{array}\right]^{T}
$$

co przedstawiono na rys. 1 .

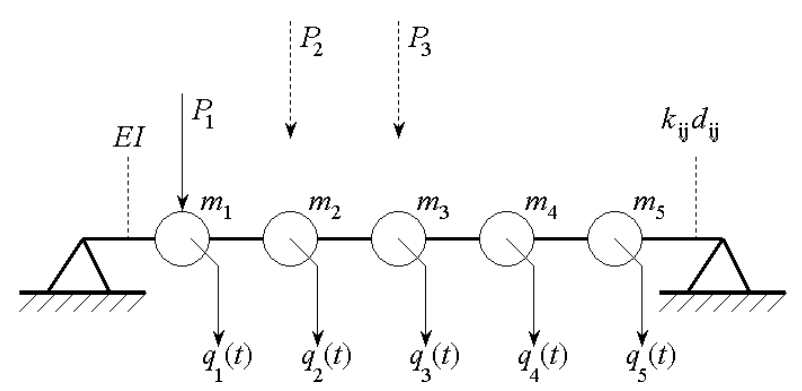

Rys. 1. Dyskretny model układu 
Po przeprowadzeniu wstępnych analiz numerycznych przyjęto macierz mas $\mathbf{M}$, macierz tumienia $\mathbf{D}$ oraz macierz sztywności $\mathbf{K}$ tak, aby charakterystyki własne modelu odpowiadały charakterystykom własnym nadwozia wagonu.

Model układu reprezentowany jest macierzą częstotliwości własnych $\Lambda$

$$
\boldsymbol{\Lambda}=\operatorname{diag}\left[\begin{array}{c}
12,10 \\
45,04 \\
97,40 \\
184,44 \\
214,14
\end{array}\right] \mathrm{Hz}
$$

macierzą postaci drgań własnych $\Psi$

$$
\boldsymbol{\Psi}=\left[\begin{array}{ccccc}
0,22 & 0,39 & 0,46 & 0,58 & 0,48 \\
0,49 & 0,58 & 0,22 & -0,39 & -0,45 \\
0,64 & -0,00 & -0,67 & -0,00 & 0,36 \\
0,49 & -0,58 & 0,22 & 0,39 & -0,45 \\
0,22 & -0,39 & 0,46 & -0,58 & 0,48
\end{array}\right]
$$

oraz wektorem bezwymiarowych współczynników thumienia d

$$
\mathbf{d}=\left[\begin{array}{l}
0,0367 \\
0,0230 \\
0,0347 \\
0,0601 \\
0,0691
\end{array}\right] \text {. }
$$

Do badań numerycznych [9] przyjęto trzy warianty wektora wejść

$$
\mathbf{B}_{1}=\left[\begin{array}{l}
1 \\
0 \\
0 \\
0 \\
0
\end{array}\right], \mathbf{B}_{2}=\left[\begin{array}{l}
0 \\
1 \\
0 \\
0 \\
0
\end{array}\right], \mathbf{B}_{3}=\left[\begin{array}{l}
0 \\
0 \\
1 \\
0 \\
0
\end{array}\right]
$$

oraz pięć wariantów wektora wyjść

$$
\begin{aligned}
\mathbf{C}_{1} & =\left[\begin{array}{lllll}
1 & 0 & 0 & 0 & 0
\end{array}\right], \\
\mathbf{C}_{2} & =\left[\begin{array}{lllll}
0 & 1 & 0 & 0 & 0
\end{array}\right], \\
\mathbf{C}_{3} & =\left[\begin{array}{lllll}
0 & 0 & 1 & 0 & 0
\end{array}\right], \\
\mathbf{C}_{4} & =\left[\begin{array}{lllll}
0 & 0 & 0 & 1 & 0
\end{array}\right], \\
\mathbf{C}_{5} & =\left[\begin{array}{lllll}
0 & 0 & 0 & 0 & 1
\end{array}\right] .
\end{aligned}
$$

Dla przyjętych wektorów wejść $\mathbf{B}_{\mathrm{j}}$ i wyjść $\mathbf{C}_{\mathrm{i}}$ wyznaczono transmitancje operatorowe o ogólnej postaci $h^{\mathrm{ij}}(s)$.
Współczynniki przy kolejnych potegach zmiennej operatorowej $s$ w liczniku i mianowniku transmitancji zapisano $\mathrm{w}$ postaci wektorów dla kolejnych transmitancji:

$$
\mathbf{b}^{11}=\left[\begin{array}{c}
2,48 \mathrm{e} 68 \\
7,03 \mathrm{e} 70 \\
6,59 \mathrm{e} 74 \\
9,88 \mathrm{e} 76 \\
4,47 \mathrm{e} 80 \\
2,51 \mathrm{e} 82 \\
6,92 \mathrm{e} 85 \\
8,19 \mathrm{e} 86 \\
1,18 \mathrm{e} 90
\end{array}\right], \quad \mathbf{b}^{21}=\left[\begin{array}{c}
1,59 \mathrm{e} 70 \\
1,62 \mathrm{e} 74 \\
6,26 \mathrm{e} 76 \\
3,03 \mathrm{e} 80 \\
2,86 \mathrm{e} 82 \\
8,58 \mathrm{e} 85 \\
1,33 \mathrm{e} 87 \\
2,27 \mathrm{e} 90
\end{array}\right]^{T}, \mathbf{b}^{31}=\left[\begin{array}{c}
-4,89 \mathrm{e} 69 \\
-4,94 \mathrm{e} 73 \\
-9,98 \mathrm{e} 75 \\
-4,56 \mathrm{e} 79 \\
7,87 \mathrm{e} 81 \\
2,79 \mathrm{e} 85 \\
1,13 \mathrm{e} 87 \\
2,49 \mathrm{e} 90
\end{array}\right]^{T},
$$

$$
\mathbf{a}^{11}=\left[\begin{array}{c}
1,48 \mathrm{e} 72 \\
5,75 \mathrm{e} 74 \\
5,44 \mathrm{e} 78 \\
1,27 \mathrm{e} 81 \\
5,89 \mathrm{e} 84 \\
6,33 \mathrm{e} 86 \\
1,82 \mathrm{e} 90 \\
6,56 \mathrm{e} 91 \\
1,18 \mathrm{e} 95 \\
9,05 \mathrm{e} 95 \\
6,25 \mathrm{e} 98
\end{array}\right]^{T}
$$

Zera dla układu ciagłego wyznaczono zgodnie ze wzorem (13). W tabeli 1 zebrano zera przy przyjęciu wejścia $\mathbf{B}_{1}$ dla kolejnych wyjść, w tabeli 2 zebrano zera przy przyjęciu wejścia $\mathbf{B}_{2}$ dla kolejnych wyjść, a w tabeli 3 zebrano zera przy przyjęciu wejścia $\mathbf{B}_{3}$.

Rozkład zer $z$ i biegunów $p$ na płaszczyźnie zespolonej dla układu ciagłego przy wejściu $\mathbf{B}_{1}$ dla kolejnych wyjść przedstawiono na rys. 2 dla wyjścia $\mathbf{C}_{1}$, rys. 3 dla wyjścia $\mathbf{C}_{2}$, rys. 4 dla wyjścia $\mathbf{C}_{3}$, rys. 5 dla wyjścia $\mathbf{C}_{4}$ oraz rys. 6 dla wyjścia $\mathbf{C}_{5}$.

$$
h^{i j}(s)=\frac{b_{8}^{i j} s^{8}+b_{7}^{i j} s^{7}+b_{6}^{i j} s^{6}+b_{5}^{i j} s^{5}+b_{4}^{i j} s^{4}+b_{3}^{i j} s^{3}+b_{2}^{i j} s^{2}+b_{1}^{i j} s+b_{0}^{i j}}{a_{10}^{i j} s^{10}+a_{9}^{i j} s^{9}+a_{8}^{i j} s^{8}+a_{7}^{i j} s^{7}+a_{6}^{i j} s^{6}+a_{5}^{i j} s^{5}+a_{4}^{i j} s^{4}+a_{3}^{i j} s^{3}+a_{2}^{i j} s^{2}+a_{1}^{i j} s+a_{0}^{i j}}
$$


Zera układu ciągłego przy wejściu $B_{1}$ dla kolejnych wyjść

Tabela 1

\begin{tabular}{|c|c|c|c|c|}
\hline \multicolumn{5}{|c|}{ Zera } \\
\hline $\mathrm{z}^{11} \cdot 1 \mathrm{e} 3$ & $\mathrm{z}^{21} \cdot 1 \mathrm{e} 3$ & $\mathrm{z}^{31} \cdot 1 \mathrm{e} 3$ & $\mathrm{z}^{41} \cdot 1 \mathrm{e} 3$ & $-10,00$ \\
\hline$-0,08 \pm 1,28 j$ & $-10,00$ & $-10,00$ & $-10,00$ & 1,71 \\
\hline$-0,04 \pm 0,87 j$ & $-0,07 \pm 1,24 j$ & $-0,07 \pm 1,15 j$ & 1,34 & $-1,46$ \\
\hline$-0,01 \pm 0,43 j$ & $-0,01 \pm 0,55 j$ & $-0,66$ & $-1,18$ & $-0,82$ \\
\hline$-0,01 \pm 0,13 j$ & $-0,01 \pm 0,17 j$ & 0,71 & $-0,03 \pm 0,80 j$ & 0,89 \\
\hline & & $-0,01 \pm 0,28 j$ & $-0,32$ & $-0,26$ \\
\hline & & & $-0,33$ & 0,26 \\
\hline
\end{tabular}

Zera układu ciągłego przy wejściu $B_{2}$ dla kolejnych wyjść

Tabela 2

\begin{tabular}{|c|c|c|c|c|}
\hline \multicolumn{5}{|c|}{ Zera } \\
\hline $\mathrm{z}^{12} \cdot 1 \mathrm{e} 3$ & $\mathrm{z}^{22} \cdot 1 \mathrm{e} 3$ & $\mathrm{z}^{32} \cdot 1 \mathrm{e} 3$ & $\mathrm{z}^{42} \cdot 1 \mathrm{e} 3$ & $-10,00$ \\
\hline$-10,00$ & $-0,08 \pm 1,26 j$ & $-10,00$ & $-10,00$ & 1,34 \\
\hline$-0,07 \pm 1,24 j$ & $-0,05 \pm 0,99 j$ & $-0,07 \pm 1,15 j$ & $0,01 \pm 0,81 j$ & $-1,18$ \\
\hline$-0,01 \pm 0,55 j$ & $-0,01 \pm 0,58 j$ & $-0,03 \pm 0,77 j$ & $-0,07 \pm 0,80 j$ & $-0,03 \pm 0,80 j$ \\
\hline$-0,01 \pm 0,17 j$ & $-0,01 \pm 0,18 j$ & $-0,01 \pm 0,28 j$ & 0,49 & $-0,32$ \\
\hline & & & $-0,47$ & 0,33 \\
\hline
\end{tabular}

Zera układu ciągłego przy wejściu $B_{3}$ dla kolejnych wyjść

Tabela 3

\begin{tabular}{|c|c|c|c|c|}
\hline \multicolumn{5}{|c|}{ Zera } \\
\hline $\mathrm{z}^{13} \cdot 1 \mathrm{e} 3$ & $\mathrm{z}^{23} \cdot 1 \mathrm{e} 3$ & $\mathrm{z}^{33} \cdot 1 \mathrm{e} 3$ & $\mathrm{z}^{43} \cdot 1 \mathrm{e} 3$ & $\mathrm{z}^{53} \cdot 1 \mathrm{e} 3$ \\
\hline$-10,00$ & $-10,00$ & $-0,08 \pm 1,26 j$ & $-10,00$ & $-10,00$ \\
\hline$-0,07 \pm 1,15 j$ & $-0,07 \pm 1,15 j$ & $-0,06 \pm 1,15 j$ & $-0,07 \pm 1,15 j$ & $-0,07 \pm 1,15 j$ \\
\hline$-0,66$ & $-0,03 \pm 0,77 j$ & $-0,01 \pm 0,42 j$ & $-0,03 \pm 0,77 j$ & $-0,66$ \\
\hline 0,71 & $-0,01 \pm 0,28 j$ & $-0,01 \pm 0,28 j$ & $-0,01 \pm 0,28 j$ & 0,71 \\
\hline$-0,01 \pm 0,28 j$ & & & & $-0,01 \pm 0,28 j$ \\
\hline
\end{tabular}

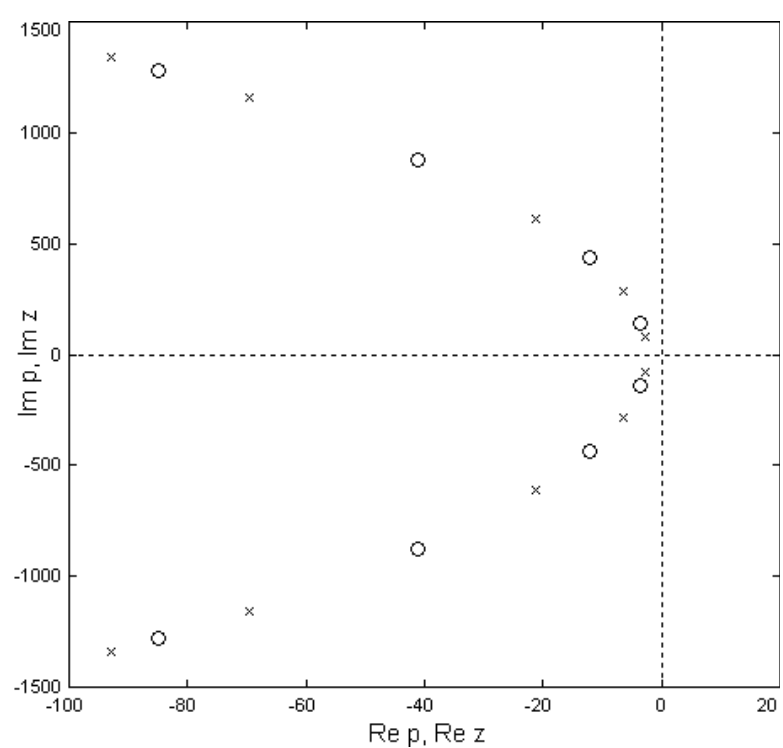

Rys. 2. Położenie zer $(\mathrm{O})$ i biegunów $(\mathrm{X})$ na płaszczyźnie zespolonej dla układu ciagłego - wejście $\mathbf{B}_{1}$, wyjście $\mathbf{C}_{1}(\operatorname{Re}$ - część rzeczywista, Im - część urojona)

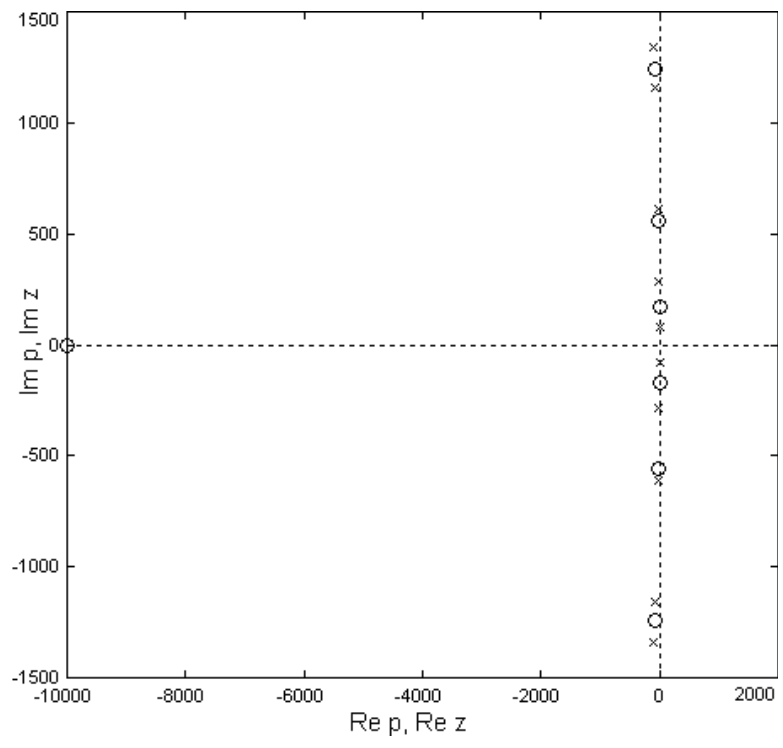

Rys. 3. Położenie zer (O) i biegunów $(\mathrm{X})$ na płaszczyźnie zespolonej dla układu ciągłego - wejście $\mathbf{B}_{1}$, wyjście $\mathbf{C}_{2}$ 


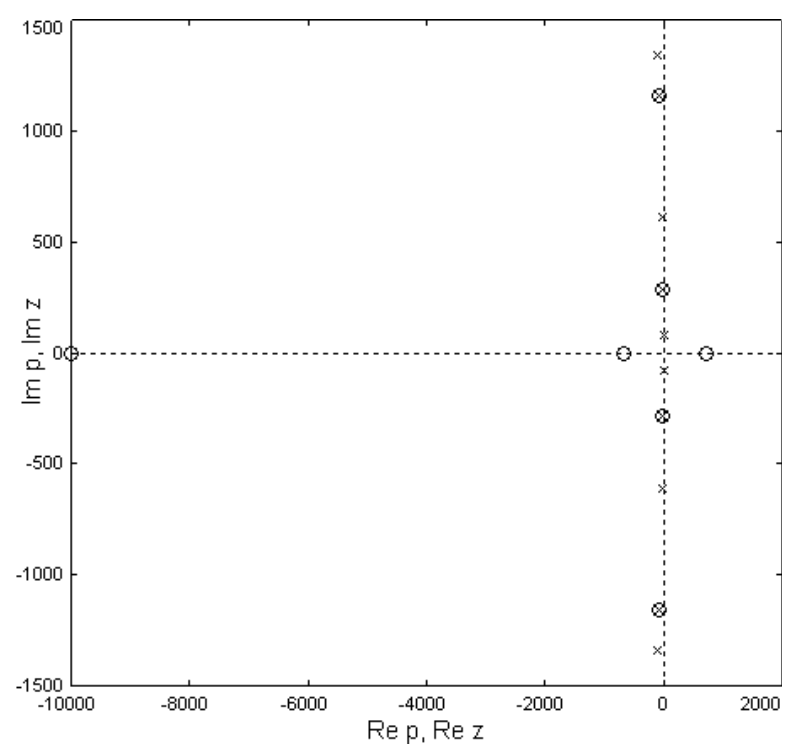

Rys. 4. Położenie zer (O) i biegunów $(\mathrm{X})$ na płaszczyźnie zespolonej dla układu ciaggłego - wejście $\mathbf{B}_{1}$, wyjście $\mathbf{C}_{3}$

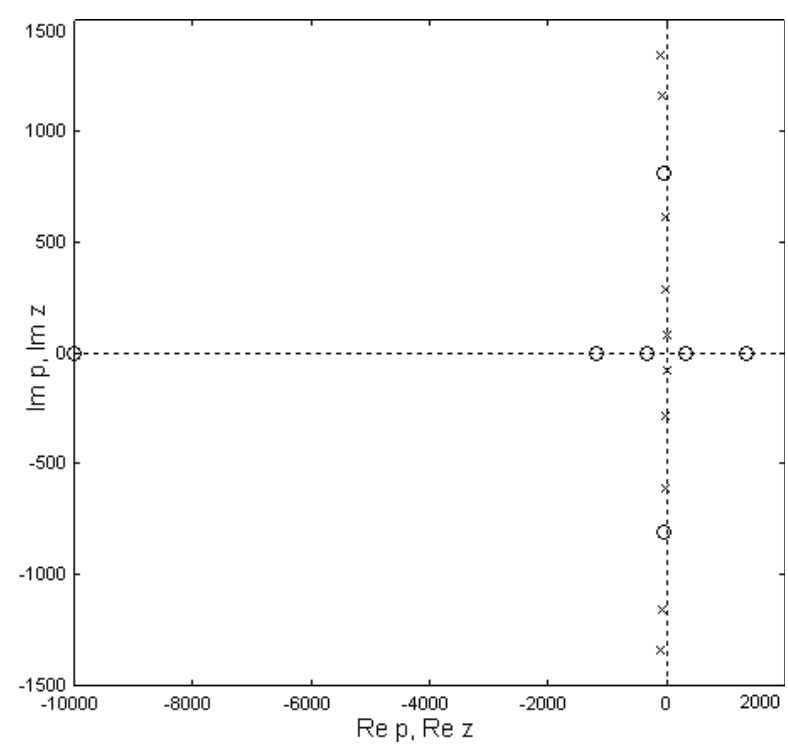

Rys. 5. Położenie zer $(\mathrm{O})$ i biegunów $(\mathrm{X})$ na płaszczyźnie zespolonej dla układu ciągłego - wejście $\mathbf{B}_{1}$, wyjście $\mathbf{C}_{4}$

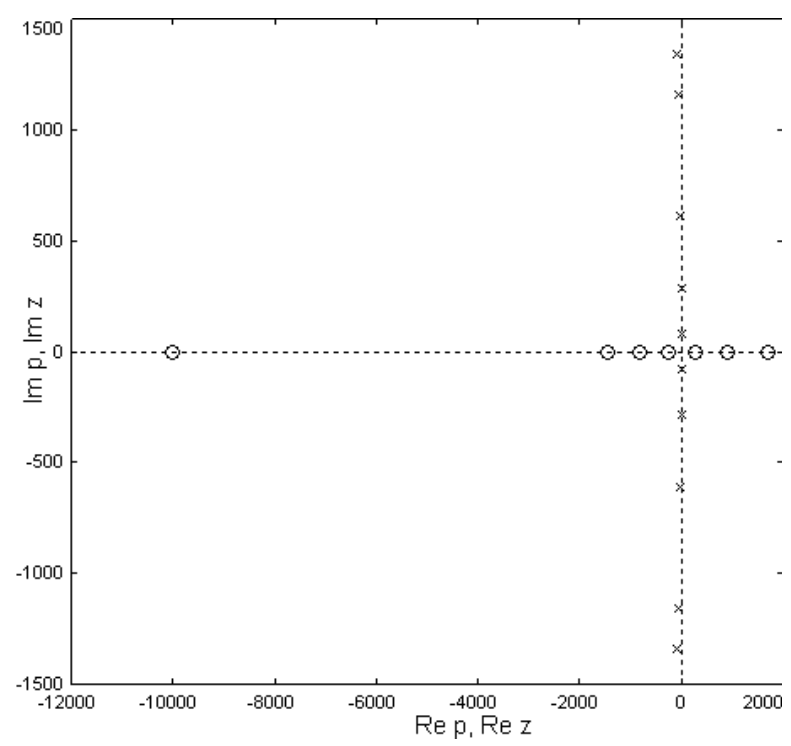

Rys. 6. Położenie zer (O) i biegunów (X) na płaszczyźnie zespolonej dla układu ciagłego - wejście $\mathbf{B}_{1}$, wyjście $\mathbf{C}_{5}$
Zera dla układu dyskretnego wyznaczono zgodnie ze wzorem (14). Przyjęto trzy warianty okresu próbkowania:

$T_{1}=0,05 \mathrm{~s}$,

$T_{2}=0,001 \mathrm{~s}$,

$T_{3}=0,005 \mathrm{~s}$.

Rozkład zer i biegunów na płaszczyźnie zespolonej dla układu dyskretnego dla okresu próbkowania równego $T_{2}$, przy wejściu $B_{1}$ dla kolejnych wyjść przedstawiono na rys. 7 dla wyjścia $C_{1}$, rys. 8 dla wyjścia $C_{2}$, rys. 9 dla wyjścia $C_{3}$, rys. 10 dla wyjścia $\mathrm{C}_{4}$ oraz rys. 11 dla wyjścia $\mathrm{C}_{5}$.

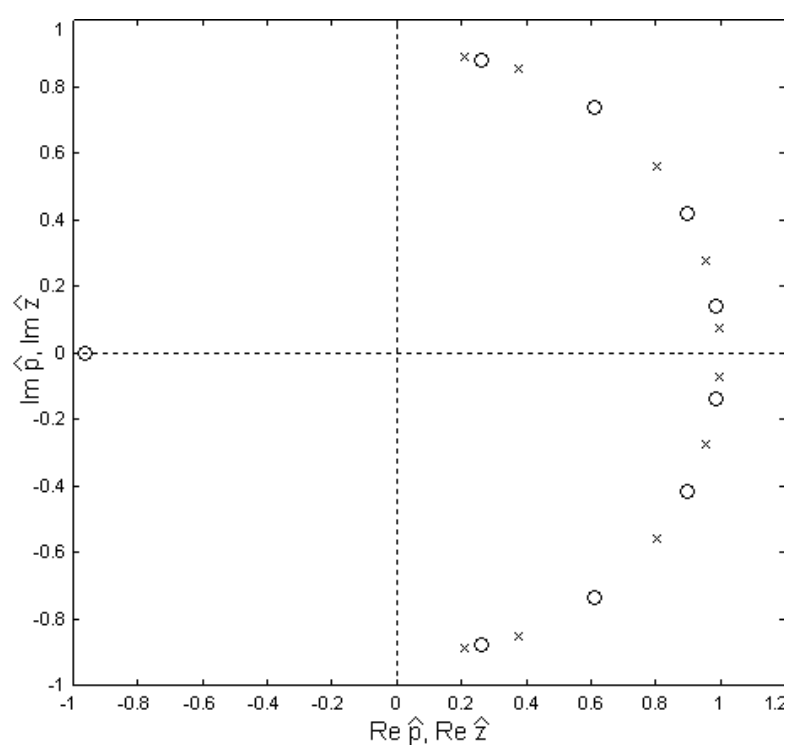

Rys. 7. Położenie zer $(\mathrm{O})$ i biegunów $(\mathrm{X})$ na płaszczyźnie zespolonej dla układu dyskretnego - wejście $\mathbf{B}_{1}$, wyjście $\mathrm{C}_{1}$

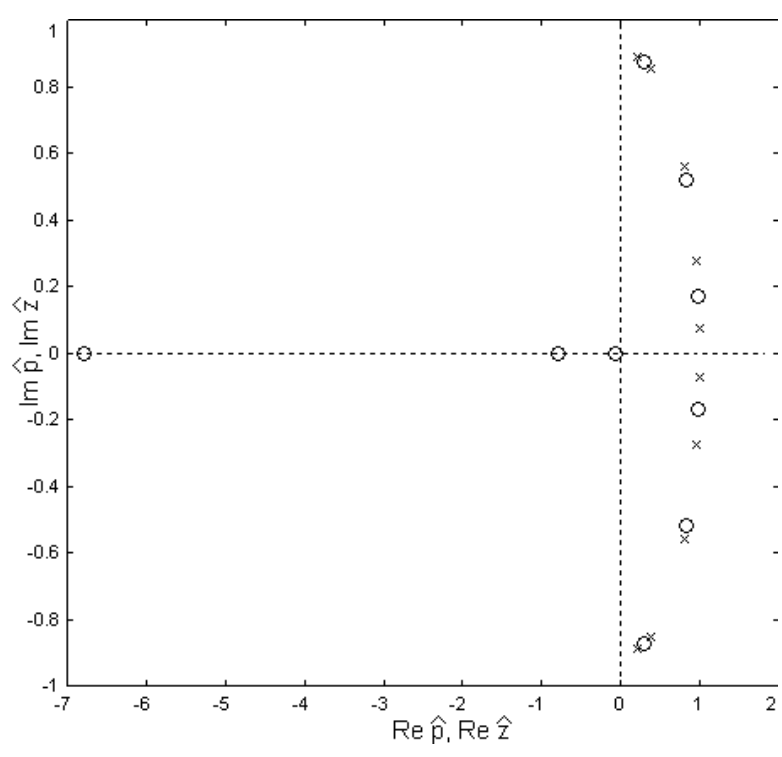

Rys. 8. Położenie zer (O) i biegunów $(\mathrm{X})$ na płaszczyźnie zespolonej dla układu dyskretnego - wejście $\mathbf{B}_{1}$, wyjście $\mathbf{C}_{2}$ 


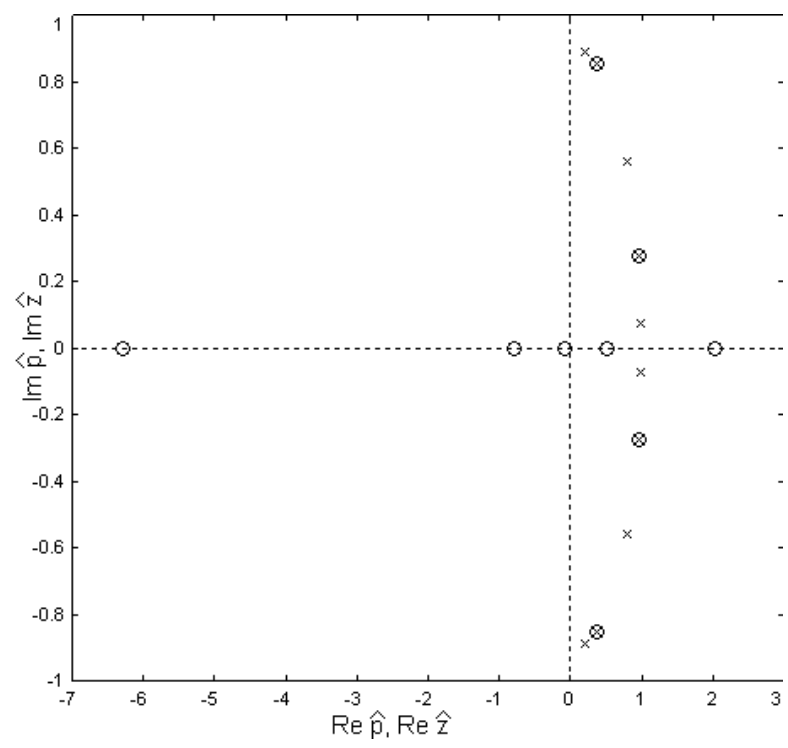

Rys. 9. Położenie zer $(\mathrm{O})$ i biegunów $(\mathrm{X})$ na płaszczyźnie zespolonej dla układu dyskretnego - wejście $\mathbf{B}_{1}$, wyjście $\mathbf{C}_{3}$

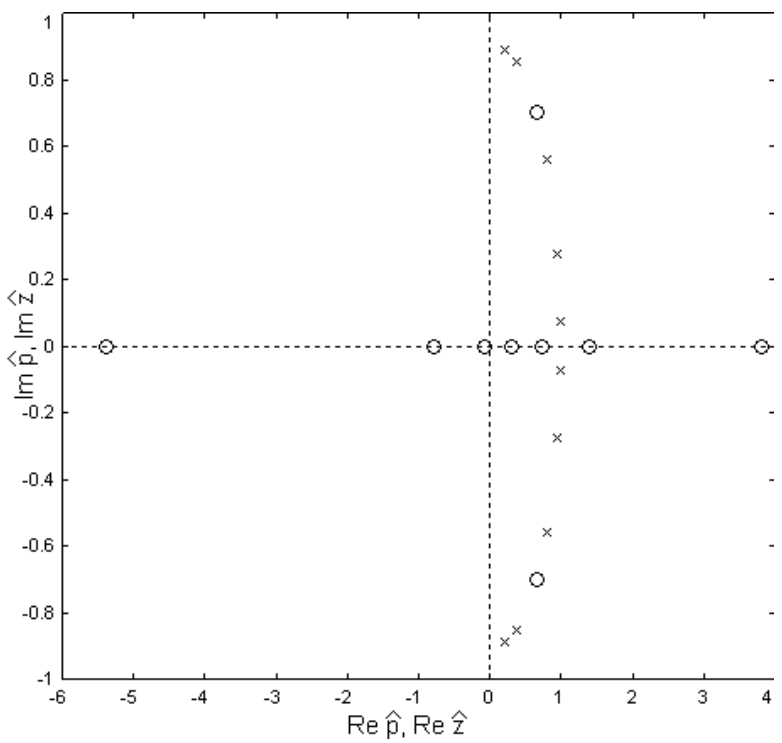

Rys. 10. Położenie zer (O) i biegunów $(\mathrm{X})$ na płaszczyźnie zespolonej dla układu dyskretnego - wejście $\mathbf{B}_{1}$, wyjście $\mathbf{C}_{4}$

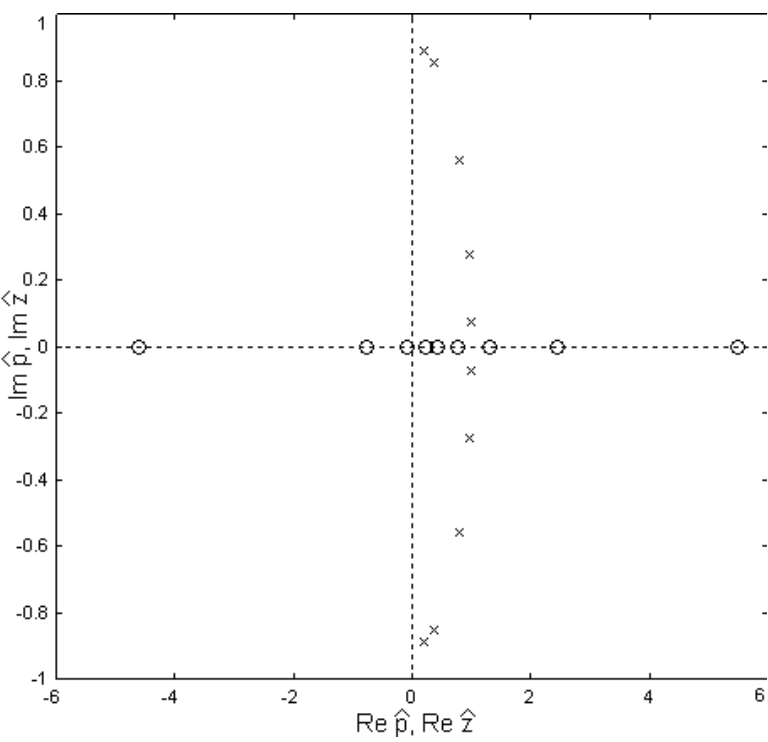

Rys. 11. Położenie zer (O) i biegunów (X) na płaszczyźnie zespolonej dla układu dyskretnego - wejście $\mathbf{B}_{1}$, wyjście $\mathbf{C}_{5}$
Rozkład zer i biegunów na płaszczyźnie zespolonej dla układu dyskretnego przy wejściu $\mathbf{B}_{1}$ i wyjściu $\mathbf{C}_{2}$, dla okresu próbkowania $T_{1}$ przedstawiono na rys. 12, dla okresu próbkowania $T_{2}$ przedstawiono na rys. 13 a dla okresu próbkowania $T_{3}$ - na rys. 14 .

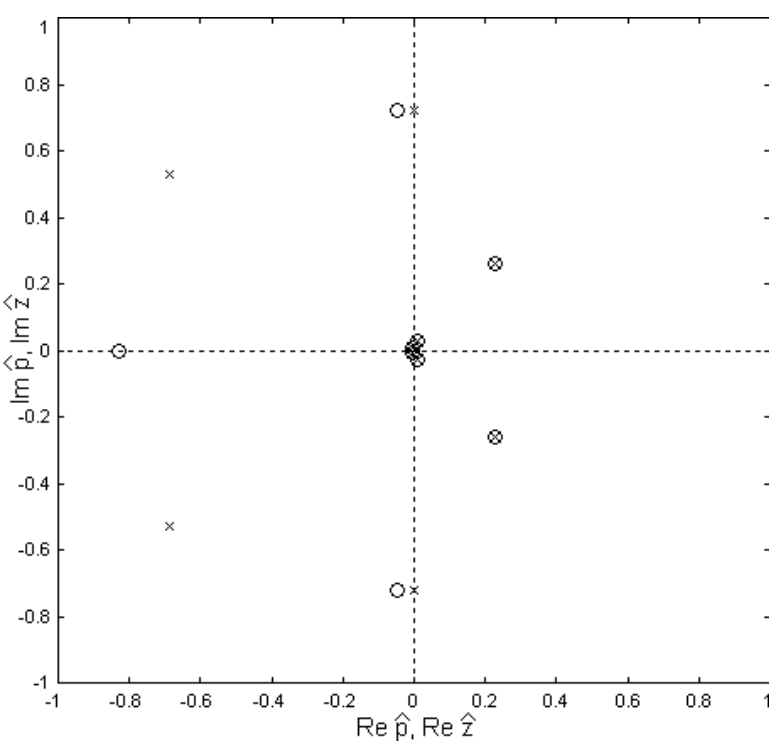

Rys. 12. Położenie zer $(\mathrm{O})$ i biegunów $(\mathrm{X})$ na płaszczyźnie zespolonej dla układu dyskretnego przy okresie próbkowania $T_{1}$ - wejście $\mathbf{B}_{1}$, wyjście $\mathbf{C}_{2}$

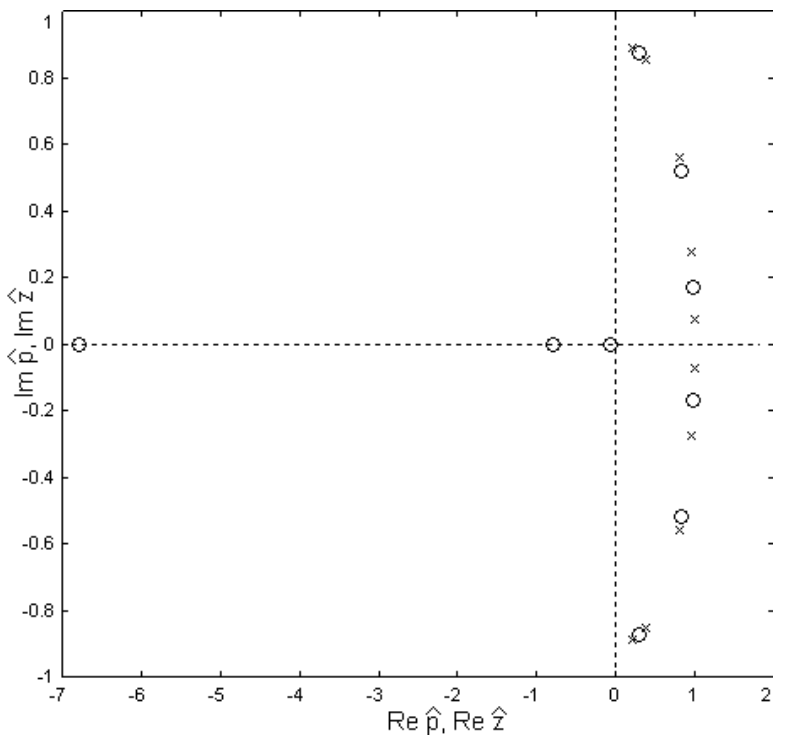

Rys. 13. Położenie zer $(\mathrm{O})$ i biegunów $(\mathrm{X})$ na płaszczyźnie zespolonej dla układu dyskretnego przy okresie próbkowania $T_{2}$ - wejście $\mathbf{B}_{1}$, wyjście $\mathbf{C}_{2}$ 


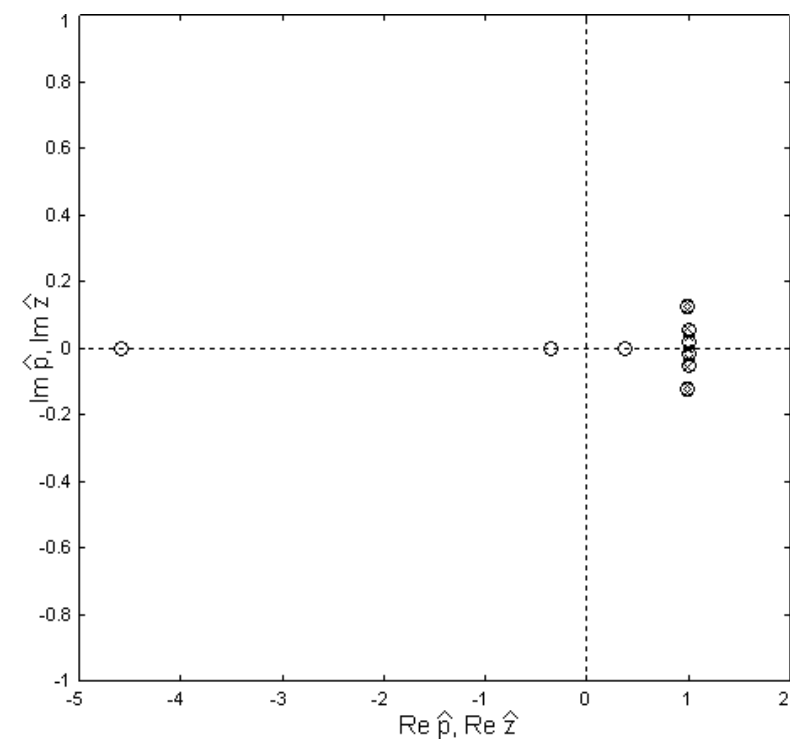

Rys. 14. Położenie zer (O) i biegunów (X) na płaszczyźnie zespolonej dla układu dyskretnego przy okresie próbkowania $T_{3}$ - wejście $\mathbf{B}_{1}$, wyjście $\mathbf{C}_{2}$

Przeprowadzone badania numeryczne układu ciagłego wykazały, że dokonywanie pomiaru na kierunku innym niż kierunek wymuszenia może spowodować nieminimalnofazowość układu (zera znajdują się w dodatniej półpłaszczyźnie zespolonej). W przypadku układu dyskretnego proces dyskretyzacji powoduje, że układ staje się nieminimalnofazowy (niektóre zera znajdują się na zewnątrz okręu jednostkowego na płaszczyźnie zespolonej).

W celu zbadania $\mathrm{w}$ jakim stopniu pominięcie wybranych modów układu wpływa na minimalnofazowość układu przeprowadzono obliczenia numeryczne, przyjmując odpowiednio dwa warianty macierzy $\Psi$ (16):

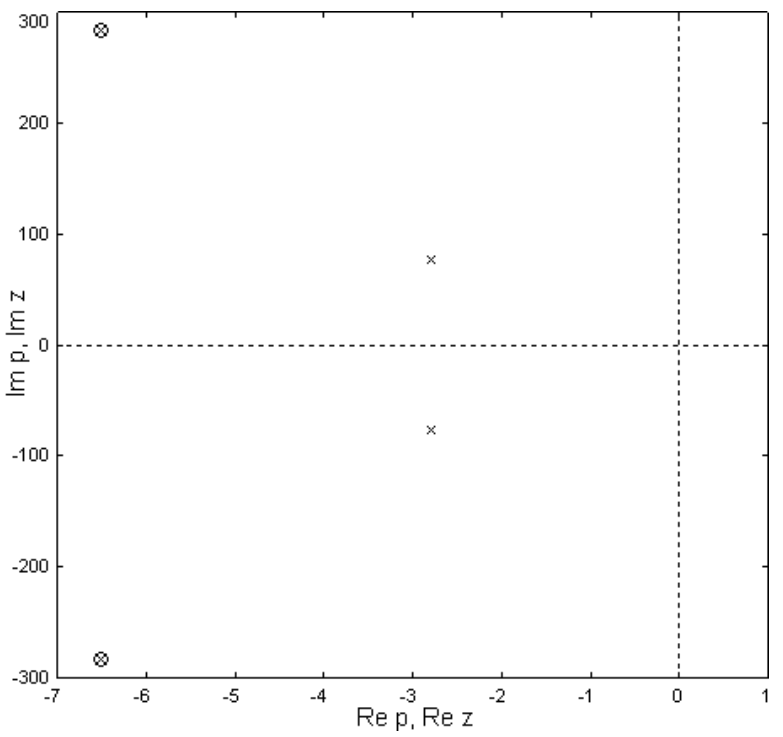

Rys. 15. Położenie zer (O) i biegunów $(\mathrm{X})$ na płaszczyźnie zespolonej dla układu ciągłego dla wejścia $\mathbf{B}_{1}$, wyjścia $\mathbf{C}_{3}$ przy przyjęciu $\Psi^{I}$
$\boldsymbol{\Psi}^{I}=\left[\begin{array}{ll}\Psi_{1} & \Psi_{2}\end{array}\right]$,

$\Psi^{I I}=\left[\begin{array}{llll}\Psi_{1} & \Psi_{2} & \Psi_{3} & \Psi_{4}\end{array}\right]$.

Rozkład zer i biegunów na płaszczyźnie zespolonej dla układu ciaggego, przy wejściu $\mathbf{B}_{1}$ i wyjściu $\mathbf{C}_{3}$, dla $\Psi^{I}$ przedstawiono na rys. 15 , a dla $\Psi^{I I}$ na rys. 16 .

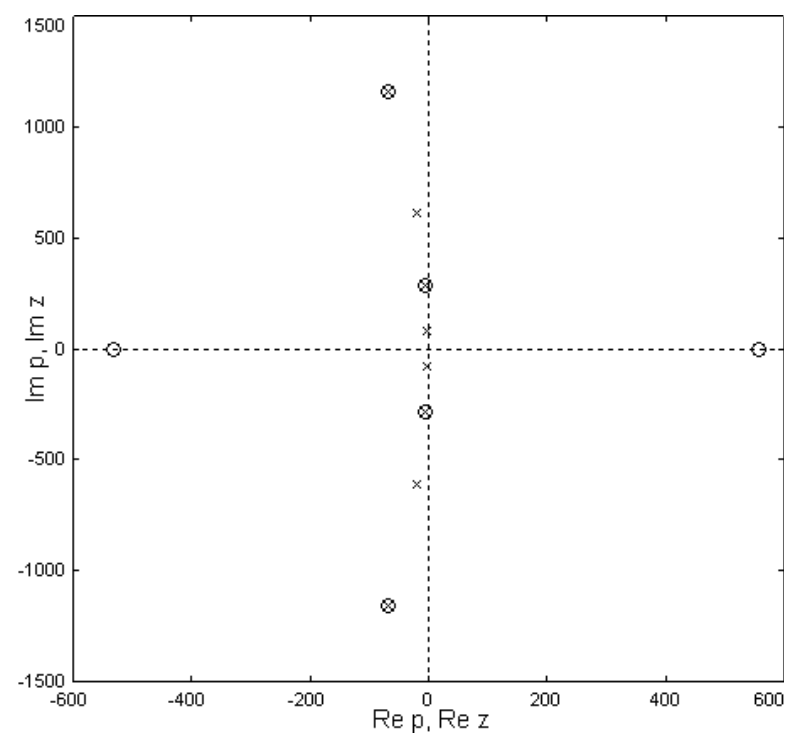

Rys. 16. Położenie zer (O) i biegunów (X) na płaszczyźnie zespolonej dla układu ciągłego dla wejścia $\mathbf{B}_{1}$, wyjścia $\mathbf{C}_{3}$ przy przyjęciu $\Psi^{I I}$

Rozkład zer i biegunów na płaszczyźnie zespolonej dla układu dyskretnego, dla okresu próbkowania $T_{2}$, przy wejściu $\mathbf{B}_{1}$ i wyjściu $\mathbf{C}_{3}$, dla $\Psi^{I}$ przedstawiono na rys. 17 , a dla $\Psi^{I I}$ na rys. 18 .

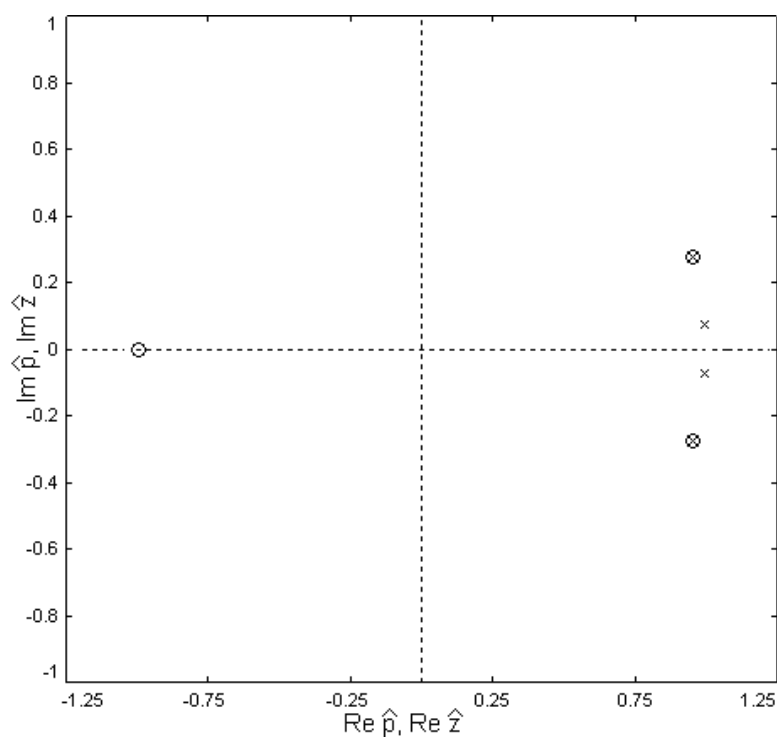

Rys. 17. Położenie zer (O) i biegunów (X) na płaszczyźnie zespolonej dla układu dyskretnego dla okresu próbkowania $T_{2}$, wejścia $\mathbf{B}_{1}$, wyjścia $\mathbf{C}_{3}$ przy przyjęciu $\Psi^{I}$ 


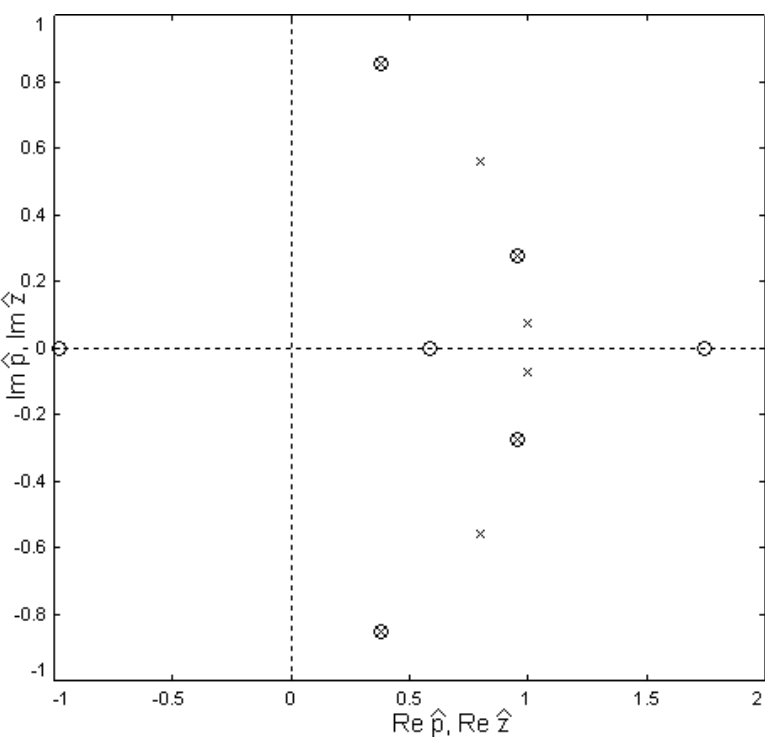

Rys. 18. Położenie zer (O) i biegunów $(\mathrm{X})$ na płaszczyźnie zespolonej dla układu dyskretnego dla okresu próbkowania $T_{2}$, wejścia $\mathbf{B}_{1}$, wyjścia $\mathbf{C}_{3}$ przy przyjęciu $\Psi^{I I}$

$\mathrm{Na}$ podstawie przedstawionych wykresów położenia zer na płaszczyźnie zespolonej stwierdzono, że przyjmując mody wedhug $\Psi^{I}$, a zatem uwzględniając dwie pierwsze postacie drgań własnych, popełnia się błąd jakościowy, ponieważ przyjmuje się, że układ jest minimalnofazowy, podczas gdy $\mathrm{w}$ rzeczywistości układ jest nieminimalnofazowy. Wynikaja $\mathrm{z}$ tego istotne konsekwencje dla jakości procesu regulacji $\mathrm{w}$ przypadku stosowania układów aktywnych lub prowadzenia badań na stanowisku symulacyjnym.

Przebiegi odpowiedzi impulsowej $\mathrm{q}_{3}$ dla układu ciągłego przy uwzględnieniu pełnej macierzy $\Psi$ oraz różnicę między odpowiedzią impulsową $\mathrm{q}_{3}$ dla układu z pełną macierzą $\Psi$ a odpowiedzią impulsową $\mathrm{q}_{3}$ dla macierzy $\Psi^{I I}$ przedstawiono na rys. 19.

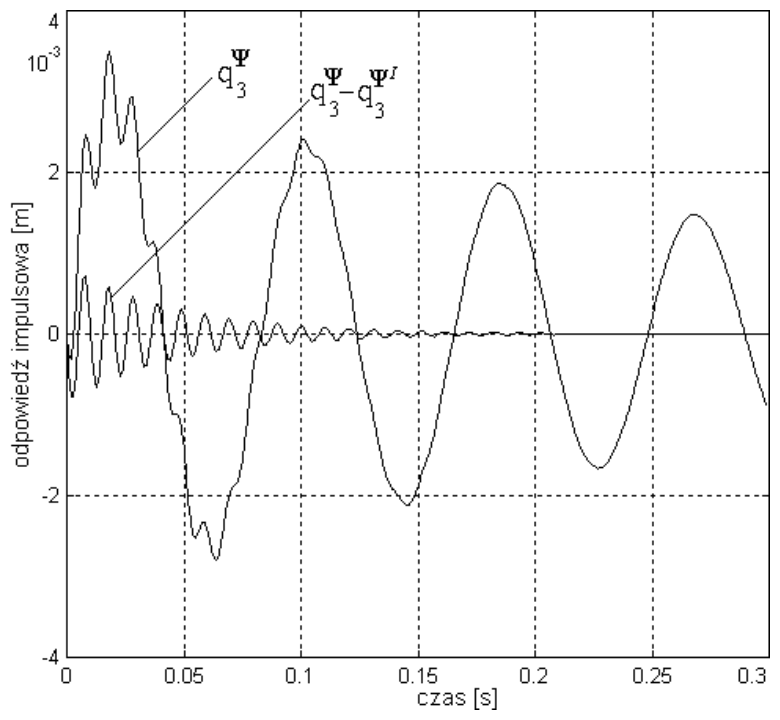

Rys. 19. Przebiegi odpowiedzi impulsowej $\mathrm{q}_{3}(t)$ dla pełnej macierzy $\Psi$ oraz błędu przy przyjęciu macierzy $\Psi^{I}$
Różnice w przebiegu odpowiedzi impulsowej $\mathrm{q}_{3}$ wyznaczonej dla układu $\mathrm{z}$ pełną macierzą $\Psi$ a odpowiedzią $\mathrm{q}_{3}(t)$ wyznaczoną przy przyjęciu odpowiednio macierzy $\Psi^{I}$ oraz $\Psi^{I I}$ przedstawiono na rys. 20.

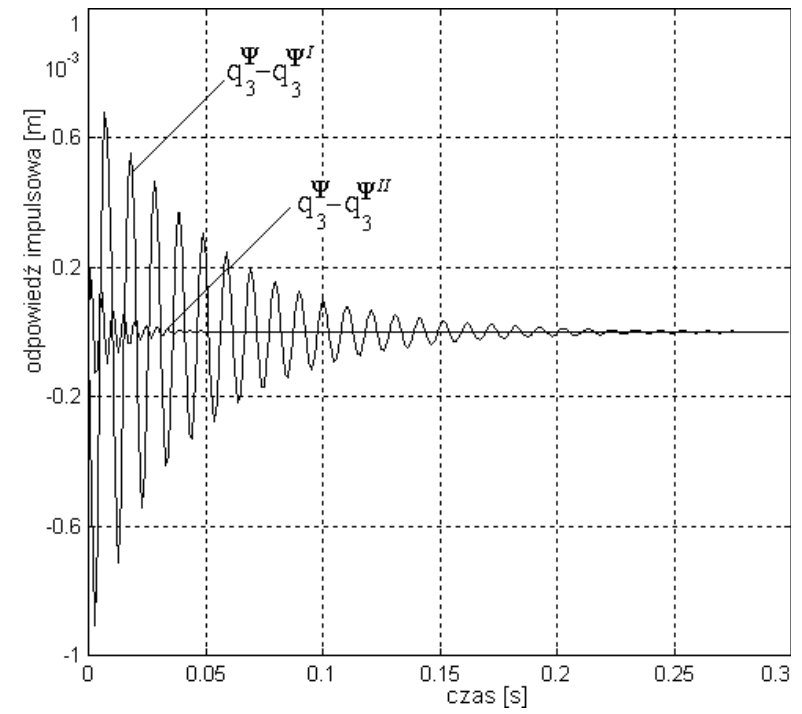

Rys. 20. Przebiegi różnic odpowiedzi impulsowej $\mathrm{q}_{3}(t)$ dla macierzy $\Psi^{I}$ oraz $\Psi^{I I}$ w stosunku do przebiegu odpowiedzi impulsowej $\mathrm{q}_{3}(t)$ przy macierzy $\Psi$

W celu określenia wpływu nieminimalnofazowości układu na stopień uwarunkowania zadania odwrotnego, polegającego na wyznaczeniu wymuszenia przy znanej odpowiedzi, dla układu wyznaczono odpowiedzi impulsowe na kierunkach $\mathbf{C}_{1}, \mathbf{C}_{2}, \mathbf{C}_{3}, \mathbf{C}_{4}$ oraz $\mathbf{C}_{5}$, przy przyjęciu wymuszenia opisanego wektorami $\mathbf{B}_{1}$, $\mathbf{B}_{2}$ oraz $\mathbf{B}_{3}$.

Przykładowe przebiegi odpowiedzi impulsowej na kierunkach $\mathbf{C}_{1}, \mathbf{C}_{2}$ oraz $\mathbf{C}_{3}$ wywołane wymuszeniem $\mathbf{B}_{1}$ pokazano na rys. 21, wywołane wymuszeniem $\mathbf{B}_{2}$ pokazano na rys. 22, a wywołane wymuszeniem $\mathbf{B}_{3}-$ na rys. 23 .

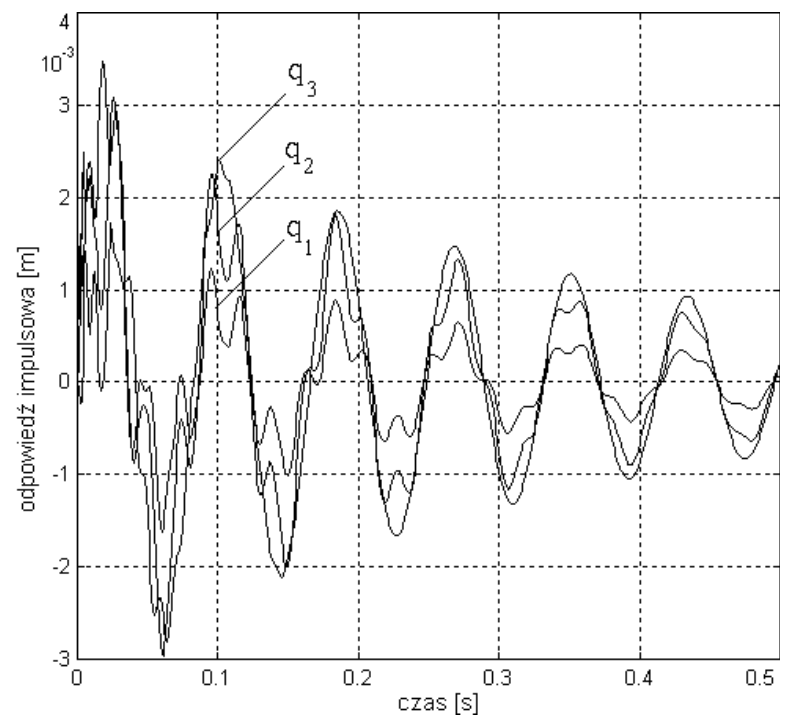

Rys. 21. Odpowiedzi impulsowe na kierunkach $\mathbf{C}_{1}, \mathbf{C}_{2}$ oraz $\mathbf{C}_{3}$ wywołane wymuszeniem $\mathbf{B}_{1}$ 


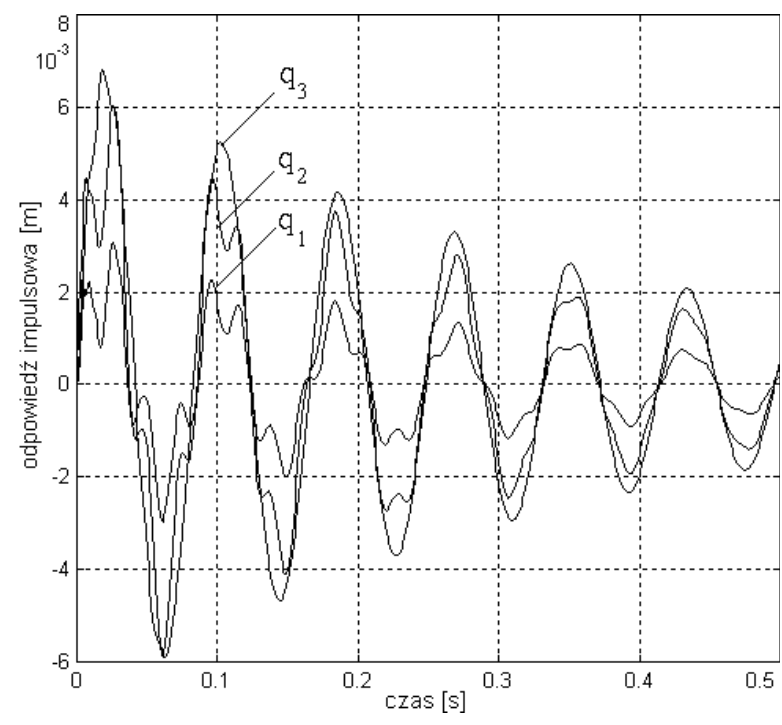

Rys. 22. Odpowiedzi impulsowe na kierunkach $\mathbf{C}_{1}, \mathbf{C}_{2}$ oraz $\mathbf{C}_{3}$ wywołane wymuszeniem $\mathbf{B}_{2}$

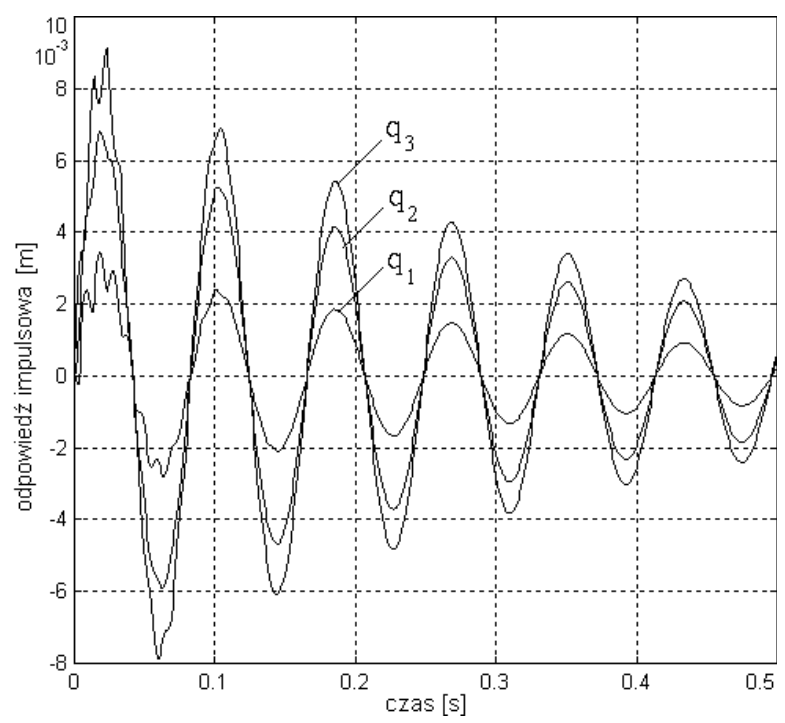

Rys. 23. Odpowiedzi impulsowe na kierunkach $\mathbf{C}_{1}, \mathbf{C}_{2}$ oraz $\mathbf{C}_{3}$ wywołane wymuszeniem $\mathbf{B}_{3}$

Dla wyliczonych odpowiedzi impulsowych utworzono macierze $\mathbf{P}$ zgodnie ze wzorem (20). Wyznaczone wartości normy macierzy $\mathbf{P}$ określające uwarunkowanie zagadnienia odwrotnego zebrano w tabeli 4.

Wartości normy macierzy $P$

\begin{tabular}{|c|c|c|c|}
\hline $\mathbf{C}_{\mathrm{i}}$ & 1 & 2 & 3 \\
\hline 1 & 199,75 & $6,25 \mathrm{e} 18$ & $\infty$ \\
\hline 2 & $1,08 \mathrm{e} 19$ & 875,98 & $2,72 \mathrm{e} 19$ \\
\hline 3 & $\infty$ & $3,79 \mathrm{e} 19$ & $1,51 \mathrm{e} 3$ \\
\hline 4 & $1,83 \mathrm{e} 20$ & $2,40 \mathrm{e} 20$ & $2,25 \mathrm{e} 19$ \\
\hline 5 & $1,99 \mathrm{e} 20$ & $1,46 \mathrm{e} 20$ & $3,27 \mathrm{e} 19$ \\
\hline
\end{tabular}

Im większe są wartości normy, tym macierz jest gorzej uwarunkowana. Analizując wartości normy określającej stopień uwarunkowania macierzy $\mathbf{P}$ stwierdzono zdecydowanie niekorzystny wpływ nieminimalnofazowości układu na rozwiązanie zagadnienia odwrotnego.

\section{Podsumowanie}

Analiza wyników przeprowadzonych obliczeń numerycznych wskazuje na istotność uwzględnienia badania problemu minimalnofazowości modelu $\mathrm{w}$ procesie tworzenia modelu typu wejście-wyjście w zakresie eksperymentalnych badań dynamiki funkcjonalnych układów pojazdów.

Stwierdzono, że badanie minimalnofazowości jest pomocne przy określaniu rzędu modelu (poprzez przyjęcie odpowiedniej liczby czujników i pomiar wielkości na odpowiednich kierunkach) dla eksperymentu prowadzonego z zastosowaniem analizy modalnej.

Stwierdzono, że błąd odtworzenia przebiegów trudno mierzalnych wielkości (szczególnie wymuszeń) w dużym stopniu zależy od tego, czy fizyczny model eksperymentu badanego układu jest minimalnofazowy.

Stwierdzono, że nieminimalnofazowość zasadniczo zwiększa złe uwarunkowanie macierzy przy rozwiązywaniu zagadnienia odwrotnego.

Uwzględnienie występowania zer układu w prawej półpłaszczyźnie zespolonej (nieminimalno-fazowość układu) jest niezwykle istotne w procesie projektowania układów regulacji symulacyjnych stanowisk badawczych. Zagadnienie to jest tematem aktualnych prac.

\section{Literatura}

[1] Bai E.-W., Wu Y.-Q., Limiting zero distribution of sampled systems, Automatica, 38, 2002.

[2] Barczak A., Zera $i$ bieguny transmitancji a częstotliwości antyrezonansowe $i$ rezonansowe układów nośnych pojazdów, Pojazdy Szynowe, Nr $1 / 2005$.

[3] Fasana A., Piombo A. D., Identification of linear mechanical systems by deconvolution techniques, Mechanical Systems and Signal Processing, 11(3), 1997.

[4] Havre K., Skogestad S., Effect of RHP zeros and poles on the sensitivity functions in multivariable systems, J. Proc. Cont., Vol. 8, No. 3, 1998.

[5] Kaczorek T., Teoria sterowania i systemów, PWN, Warszawa, 1993.

[6] Kaczorek T., Wektory $i$ macierze $w$ automatyce $i$ elektrotechnice, WNT, Warszawa 1998.

[7] Moheimani S. O., Minimizing the Effect of Out of Bandwidth Modes in Truncated Structure Models, Journal of Dynamic Systems, Measurement, and Control, Vol. 122, 2000.

[8] Sidi M. J., Loop-gain optimization of unstable-nonminimum phase feedback systems, International Journal of Control, Vol. 77, 2004.

[9] MATLAB wersja 5.3. 